\title{
Evaluation of collaborative strategies for ecotourism and recreational activities in natural parks of Rio de Janeiro*
}

Marcos Cohen**

Jorge Ferreira da Silva***

Summary: 1. Introduction; 2. Theoretical framework on sustainable development and ecotourism; 3. Research method; 4. Research results; 5. Discussion of results; 6. Conclusions and recommendations.

Sumário: 1. Introdução; 2. Referencial teórico sobre desenvolvimento sustentável e ecoturismo. 3. Metodologia de pesquisa. 4. Resultados. 5. Discussão. 6. Conclusões e recomendações.

KEY WORDs: ecotourism; recreational activities; collaborative strategies; natural parks.

Palavras-chave: ecoturismo; atividades de recreação; estratégias colaborativas; parques naturais.

In the city of Rio de Janeiro, the management agencies of environmental conservation units of the park type have been attempting to meet five primary objectives set by the National System for Conservation Units (NSCU), using participatory management guidelines for these units. Two of these objectives relate to the development of recreation activities that involve contact with nature and ecological tourism. This article presents the analyses and conclusions regarding the implementation of collaborative strategies with businesses to achieve such objectives; it is part of a series of research studies having a broader scope. Case studies were conducted in eight parks by means of dozens of interviews with managers and other interested

* Article received in May 2010 and accepted in Aug. 2010.

** Professor of strategy at Pontifícia Universidade Católica (PUC-Rio). Address: Rua Marquês de São Vicente, 225 — Gávea — CEP 22451-900, Rio de Janeiro, RJ, Brasil. E-mail: mcohen@iag. puc-rio.br.

$* * *$ Professor of strategy at Pontifícia Universidade Católica (PUC-Rio). Address: Rua Marquês de São Vicente, 225 - Gávea — CEP 22451-900, Rio de Janeiro, RJ, Brasil. E-mail: shoshop@ iag.puc-rio.br. 
social actors, as well as by documentary research and direct observation. The results suggest that the ecotourism objective is still far from being reached, and that the collaborative strategies used are not sufficient to compensate for the organizational, material and human limitations that encumber these agencies. It was also concluded for the sample that there lacks a strategic vision on the part of the three branches of government involved in the management of these parks in the sense of viewing ecotourism in the city's conservation units as a powerful means to foster local sustainable development.

\section{Avaliação de estratégias colaborativas para atividades ecoturísticas e recreativas em parques ecológicos do Rio de Janeiro}

Na cidade do Rio de Janeiro, as agências gestoras de unidades de conservação ambiental do tipo parque vêm tentando atingir cinco objetivos principais estabelecidos pelo Sistema Nacional de Unidades de Conservação Ambiental (SNUC), adotando diretrizes de gestão participativa para essas unidades. Dois desses objetivos referem-se ao desenvolvimento de atividades recreativas que envolvem o contato com a natureza e o ecoturismo. Este artigo apresenta as análises e conclusões relativas à implementação de estratégias de colaboração com empresas para atingir tais objetivos. Ele é parte de um conjunto de pesquisas mais amplo. Foram realizados estudos de caso em oito parques, por meio de dezenas de entrevistas com gestores e outros atores sociais interessados, assim como pesquisa documental e observação direta. Os resultados sugerem que o objetivo ecoturístico está longe de ser alcançado e que as estratégias colaborativas utilizadas são insuficientes para contrabalançar as limitações organizacionais, materiais e humanas que sobrecarregam essas agências. Com base na amostra, concluiu-se também que os três poderes de governo envolvidos na gestão dos parques carecem de uma visão estratégica, no sentido de considerar o ecoturismo nas unidades de conservação da cidade como um meio poderoso de incentivar o desenvolvimento local sustentável.

\section{Introduction}

The last third of the $20^{\text {th }}$ century witnessed enormous growth in alternative tourism, a smaller-scale tourism than conventional mass tourism, a tourism focusing on specific areas of interest such as culture, gastronomy etc. Ecotourism, or ecological tourism, is a type of alternative tourism - one that embraces visiting natural areas, combined with the theoretical responsibility of preserving such environments (Cater, 1993). According to Western (1999), ecotourism is, in truth, a set of interests that arise from concerns of an environmental, economic and social order. These definitions conform with those of the International Ecotourism Society (2001): "Responsible travel to natural areas that conserves the environment and improves the well-being of local people". 
Because ecotourism has become a multimillion dollar worldwide industry in recent years, it could have the capacity to provide economic means for the conservation of the object environments. However, several environmental researchers and conservationists have commented on the growing degradation of natural environments frequented by tourists (Orams, 1995; Davenport and collaborators, 2002). Although for some defenders of environmental conservation, true ecotourism is confined to low-volume tourism with a focus on environmental issues, for others, such a vision is idealist and does not reach sufficient numbers to foster the conservation thus proposed. More recently, the term "sustainable tourism" has been employed as a more complete concept, since it would involve the basic premises of ecotourism, but also include mass tourism from the perspective of sustainability, as defined in the Brundtland Report (Oliveira, 2004). In fact, it would be necessary to attract, and increase the awareness of, a sufficiently large number of tourists to generate the economic profits that could enable the deployment of conservationist objectives, in conjunction with improved living conditions for local populations, from the perspective of sustainable development. What emerges from this polemic is that ecotourism exhibits intrinsically contradictory characteristics. It has the capacity to provide great opportunities for the conservation of natural areas, but, at the same time, built into its activities are the risks associated with tourism that can destroy nature. In harmony with the second line of thinking, Ross and Wall (1999) state that ecotourism's main objective should be to ensure the means of conservation for natural areas, through the generation of income, environmental education and involvement of local populations. Such a definition touches on several questions fundamental to the practice of ecotourism, seen from the perspective of sustainable development.

With the objective of guaranteeing the preservation and/or sustainable use of a range of areas in Brazil with relevant natural characteristics, Law 9985 was passed in 2000 which created the National System for Conservation Units (NSCU) and which regulates the management of different types of environmental conservation units in the country. These units include the integral conservation units (ICU), whose basic objective is to preserve nature, with only the indirect use of their natural resources being committed, with the exception of cases provided for under the NSCU law. As such, environmental extraction and farming are strictly forbidden in these units (Brazil, 2000, chapter III, article 7, paragraph 1). One of the most common forms of UCI is the natural park. NSCU identifies five main objectives for a natural park (Brazil, 2000; chapter III, article 11): preserve natural ecosystems of great ecological importance and scenic beauty; foster the development of scientific research; develop activities 
for environmental education and interpretation; develop recreation activities that include contact with nature; develop ecological tourism (ecotourism).

These objectives, if achieved effectively, may contribute to the sustainability of the conservation unit and the surrounding communities. The NSCU itself establishes guidelines which would help to achieve these objectives in a collaborative and participative way (Brazil, 2000, chapter II, article 5), that in which the managing agencies of conservation units must seek

the support and cooperation of nongovernmental organizations, private organizations and individuals for the development of studies, scientific research, environmental education practicums, leisure and ecological tourism activities, monitoring, maintenance, and other conservation unit management activities.

The Management Plan, drafted on the basis of community input, is an instrument to be developed participatively, and that will help the Conservation Unit to define how ecotourism should be implemented and managed.

In this new context, the city of Rio de Janeiro has a special incentive for environmental conservation. In 2006, there were, in Rio, dozens of conservation units, among which stood out 17 municipal natural parks, three state parks and one national park. Each one of these parks is administered by the environmental agency responsible within the respective government sphere, which nominates an agency staff member to act as park manager. These parks are potential generators of jobs and income for the surrounding population, by means of employment in the range of support services to the unit management and activities related to tourism. Meanwhile, recent audits show that many of these parks lack sufficient infrastructure and the financial, human, and management resources to comply with the directives and objectives advocated by NSCU, including the planning and implementation of ecotourism projects (PCRJ-SMAC, 2004; TCMRJ, 2005).

The main issues that emerge in the face the situation outlined above concern how activities to promote recreation and ecotourism in natural parks in the city of Rio de Janeiro are being planned and managed and whether the results have been effective in terms of sustainability. In the light of the participative guidelines of the NSCU, it is important to understand which collaborative strategies have been deployed by the managers of these parks, within the context of such management guidelines. As such, this paper presents the results and conclusions of a larger study that analyzed the collaborative strategies used in the management of eight city parks vis-à-vis the NSCU's advo- 
cated objectives and guidelines. This article focuses only on the objectives related to recreation in contact with nature, and ecotourism.

\section{Theoretical framework on sustainable development and ecotourism}

Starting in the 1970s, with the growth of the ecological movement and an awareness of the need to preserve the environment, and parallel with the perception that tourism in areas of environmental interest was damaging the biodiversity, concerns arose regarding how to ally tourism with the conservation of visited areas (Ceballos-Lascuráin, 1999). Then, the economic question began to be looked at, since in many cases, only through touristic visits is it possible to raise the funds necessary for the conservation of the nature of the locale. In cases where local traditional communities depend on the natural environment (fishing, gathering) that is also the conservationists' point of focus, the interests at stake may appear to be incompatible, environmental conservation may be at odds with the economic sustainability of these populations. Thus, social concerns must also be taken into account (Ross and Wall, 1999). Integration of the environmental, with the economic and social, characterizes an approach of sustainable development, typical of what many today call ecotourism, despite the various definitions and interpretations attributed to the term (Orams, 1995; Scheyvens, 1999; Davenport and collaborators, 2002). Starting in the 1990s, the question of sustainability began to be conceptualized more clearly, with current consensus being that ecotourism should attempt to harmonize the needs of the environment, the local community, visitors, and touristic activities, ecological trail hiking, mountain climbing, wildlife watching, amateur photography/video making etc. (Costa, 2002). Only thus, could ecotourism help to conserve/recuperate the natural areas, revitalizing the culture and contributing to the socioeconomic development of the local communities. In this way, ecotourism can be defined as a function of its fundamental and concomitant goals of conservation of natural areas, low visitor impacts, and the socioeconomic development of local communities.

However, for Western (1999), ecotourism is becoming less defined as small-scale nature tourism, and is developing into a set of principles applicable to any kind of tourism that interfaces with nature. Ross and Wall (1999) share this vision and believe that ecotourism's main objective would be to assure means of conservation for natural areas, through the generation of income, environmental education and involvement of local populations. Ross 
and Wall argue in their ecotourism model that ecotourism's basic functions include (along with providing an agreeable nature experience) the protection of natural areas, income generation, education and local capacity building/participation, that, combined, would attain certain specific objectives, within the concept of sustainable development, in order to resolve the conflict between the exploitation and conservation of natural resources.

However, defining sustainable development is a complex task, due to the need to take its systemic multidimensionality into account (Sachs, 1993). Yet measuring sustainable development is a task even more complex. Several authors have dedicated themselves to identifying the best way to measure the degree of sustainability of conservationist actions or the development of a determined region, without, however, arriving at any consensus regarding the best method. There is, however, agreement with respect to the need to take into account indicators related to the economic, social and environmental results in the evaluation (Egler, 1999), even though the cultural and spatial dimensions cannot be ignored, as proposed by Sachs (1993). Therefore, when analyzing the ecotourism management of a conservation unit, a specific set of indicators must be developed in order to adequately measure whether such objectives are being reached. This means that the Management Plan must include the task of designing a specific set of indicators that adequately measure the range of objectives encompassed by the NSCU.

Davenport and collaborators (2002) propose a methodology for planning the management of the visible impacts of ecotourism in parks, including the development and selection of key impact indicators. Considering the operationalization of ecotourism, several authors defend the adequate management of ecotourism ventures. This management can be divided into several stages, i.e., selection of environmental area; planning the ecotourism project best suited to the needs of the environment and the local population; implementation of the project, from fundraising through mobilization of involved stakeholders; and project management, including measuring of results to compare them with stated goals. Cater (1993) proposes that it is essential to recognize that without an adequate understanding of the pertinent factors and careful planning/management, ecotourism can foster unsustainable aspects. Almeida and collaborators (1999) note that during the planning stage, any possible harm must be taken into account that could be caused to the environment as a function of the fragility of the natural ecosystems vis-à-vis an excessive number of visitors or heavy vehicular traffic, for example, or even the installation of infrastructure beyond that of preestablished regulations. Another risk 
to be evaluated is the negative impacts of visitors on the values of the local population, possibly sparking conflicts of a moral and cultural nature. So, in order to diminish the chance of negative impacts of ecotourism-related activities, strategic planning is required. Such planning must take into account the general features of the ecosystem, in order for rules for implementing touristic activities to be laid out, including limiting the maximum numbers of visitors, limiting traffic flow, adoption of parameters to build infrastructure etc. Seabra (2001) agrees with Almeida and collaborators (1999) in emphasizing that planning/management of conservation units for the purpose of implementing touristic ventures should conform to technical-scientific and legal-institutional criteria, comply with applicable law, and respect private property and the local culture of traditional peoples. Thus, Seabra (2001) proposes a methodology for implementing an ecotourism program in conservation units, comprising several stages, summarized as follows: diagnostics and identification of the local tourism potential; tourism/ecology/economic planning; acquisition of financial, material and resources; activities programming and publicity; implementation, ongoing monitoring/evaluation. Boyd and Butler (1996), in contrast, proposed a structure based on eight components for the identification of opportunities and the management of ecotourism, something they refer to as the "ecotourism opportunity spectrum". The components are access, other resource-related activities, attractions offered, existing infrastructure, social interaction, level of skill and knowledge, acceptance of visitor impacts and acceptance of a management regime. Another viable option is the use of public-private partnerships to manage ecotourism in natural parks. In Brazil, Pasquali (2006) discusses the great potential of including private initiatives in ecotourism services inside Chapada dos Guimarães National Park (Mato Grosso, Brazil), thereby freeing up the management agency (Ibama) to perform its original role, conserve the park environment.

Alternatively, Ross and Wall (1999) present a theoretical construct the "ecotourism paradigm" - which seeks to relate tourism with local communities and the biological diversity, emphasizing that one should attempt to foster positive reinforcement of the links between these three elements in order that the end result be greater than the sum of the parts. Based on this construct, they suggest a set of relevant indicators should be posited to evaluate ecotourism at the location, based on talks with stakeholders; they also discuss in greater detail the model's interrelationships. Along the same lines, Ross and Wall (1999) concede that their own construct is viable only when there is effective management of the process, through suitable institutional 
arrangements and administrative commitments, including the formulation of policies, management strategies, and the involvement of a broad range of organizations, including nongovernmental organizations (NGOs) and development/conservation agencies in areas undergoing development. Additionally, the quality of the policies employed to protect the environmental area, as well as individuals charged with their implementation will have a large impact on the results. Ross and Wall (1999) underscore the role of NGOs, research teams, and development agencies in developing countries, as suppliers of qualified resources, databases and general knowledge, through education and the creation of opportunities for building up local skill levels by means of training. This point introduces a question critical to the management of ecotourism projects: the participation of stakeholders throughout the process. In a research study recently conducted at Parque Estadual da Serra Dourada (Goiás, Brasil), Barbosa (2008) concluded, based on a tourism inventory, that there is enormous potential for the development of ecotourism in that area. However, she considers the rising political awareness in civil society a fundamental factor for this potential to be realized.

For Presas (2001), for example, the transition to sustainable development entails a new way of thinking based on - no longer using the traditional vertical top-down approach - a mechanism of collective learning, the fruit of dialogue between the social actors. But this can only happen if the social actors are aware of their individual roles, of the interdependencies, and of the need for partnerships. Thus, a wide and democratic debate would be essential for the proper identification of the relevant issues, the setting of priorities, and the definition of viable action plans, based on the (oftentimes conflicting) positions of these stakeholders. Such a strategy has also been defended by Valladares-Padua and collaborators (2001). According to Ross and Wall (1999), those responsible for the project must maintain a level of dialogue that, enables an understanding of local requirements (thereby avoiding the adoption of measures that could jeopardize local communities); fosters greater community decision-making power; creates/consolidates stakeholders; produces local ecological leaders; and builds local capacity for monitoring and evaluation of ecotourism project progress. In this new context, traditional strategies for development - based on purely economic criteria and without stakeholder participation in the planning process or in decision-making - are no longer viable. What is needed is a socioenvironmental focus that takes into account the interests of stakeholder networks - especially the local community, which will eventually influence the direction and the results of the ecotourism programs that will affect them. 


\section{Research method}

This article is based on a synopsis of two of the dimensions studied in the context of a larger study, an approved doctoral thesis. First, an exploratory research study was carried out using a qualitative approach (Creswell, 2003), operationalized by means of a multiple-case-study strategy (Yin, 1994), with the objective of increasing the capacity to generalize, based on the research. The reliability of the research was assured by means of a case study protocol and a continuous process of triangulation of the data sources, following Yin (1994).

Of the original universe of twenty-one parks, eight were selected to represent the three spheres of government, as shown in chart 1 . Two parks stand out in terms of size - Tijuca National Park and Pedra Branca State Park. Of the six municipal parks, the majority with areas of less than 100 hectares, five are located in Jacarepagua west district, which covers the neighborhoods of Barra da Tijuca, Recreio and Freguesia- the part of the city where the greatest pressure on urban growth has occurred in the last twenty years.

Chart 1

Basic information on the parks studied

\begin{tabular}{|lccll|}
\hline Natural Park & $\begin{array}{c}\text { Government } \\
\text { agency }\end{array}$ & $\begin{array}{c}\text { Area in } \\
\text { hectares }\end{array}$ & \multicolumn{1}{c|}{ Location in the city } & $\begin{array}{c}\text { Management } \\
\text { plan }\end{array}$ \\
\hline Tijuca & Federal & 12,500 & $\begin{array}{l}\text { Several neighborhoods in South } \\
\text { and North district }\end{array}$ & Yes \\
Pedra Branca & State & 3,563 & $\begin{array}{l}\text { Several neighborhoods in West } \\
\text { and North district }\end{array}$ & In progess \\
Marapendi & Municipal & 971 & Recreio / Barra - West district & No \\
Prainha & Municipal & 147 & Grumari - West district & No \\
Bosque da Barra & Municipal & 50 & Barra- West district & No \\
Chico Mendes & Municipal & 40 & Recreio - West district & No \\
Bosque da Freguesia & Municipal & 31 & Freguesia - West district & No \\
Penhasco Dois Irmãos & Municipal & 25 & Leblon - South district & No \\
\hline
\end{tabular}

Note: 1 square mile $=259$ hectares; 1 square $\mathrm{Km}=100$ hectares.

The semistructured interviews were conducted based on a list of preformulated open-ended questions. Seventy-one in-depth interviews were analyzed. The interviewees comprised representatives from the central ma- 
nagement agency (Municipal Secretariat for the Environment - Smac), park administrators, and representatives from a range of groups of social actors interested in the management of the parks (companies, NGOs, trade organizations etc.). Data was also obtained by means of bibliographic and documentary research, as well as ample direct observation, inside the parks. The data collection phase lasted from November 2005 to December 2006, with a final follow-up between January and March of 2007. Important data referring to parks operations and maintenance status, and statistics concerning visiting and education activities, were obtained from government agency audits. Treatment of the data was eminently qualitative, with Atlas.ti 4.2 content analysis software being used. The data were tabulated in order to aid the researcher in the comparative analysis among cases.

In order to analyze the sustainability of the ecotourism strategies used in each park, the model advanced by Ross and All (1999) was used, in conjunction with the traditional concept of sustainable development in the Bruntland Report (Egler, 1999). In this way, the researcher analyzed the comments and qualitative evaluations of the seventy-one interviewees with respect to aspects related to:

v economic dimension - capacity to generate income to support the park, generation of business opportunities and income for the population surrounding the park;

v environmental dimension - capacity to preserve park flora and fauna, and diversity, capacity to handle threats posed by local inhabitants and tourists, environmental impacts of visits on flora and fauna, improvements in park infrastructure;

v social dimension - capacity to generate improvements in infrastructure of the communities surrounding the park, as a result of ecotourism. Generation of jobs/internships for local inhabitants, enhanced interaction with the community and recognition of the park has an important place for these inhabitants, use of ecotourism for environmental education and motivation of youths/children for its preservation.

The cultural dimension proposed by Sachs (1993) in his eco-development concept was not used: it was thought that in the case of urban parks, the local urban culture is little affected by the exploitation of park tourism. That said, it is also conceded that this could be a methodological limitation of the research. 
Based on the interviews, a "qualitative" assessment of the contribution of management collaborative strategies to each of the three sustainable dimensions of ecotourism was performed, using the following scale: very low, low, fair, high, very high. The average resulting assessment helped conduct an initial and limited evaluation of the sustainability of the ecotourism strategies and managerial actions of the parks under study.

This research suffers of other three major limitations. First, due to the methodology adopted in the study, the results cannot be generalized to other parks inside and outside the city. In spite of this, the limit to generalize is mitigated somewhat, due to the fact that the sample represented the majority of the operating parks in Rio, two of them being the city's most important parks. Second, although triangulation - the use of different types of sources and several interviews for each case - reduces the risk of perceptual biases from interviewees, there is still the potential of the researchers' bias in interpreting the results. Third, the selection of conservation units might have biased our results.

\section{Research results}

Below is a presentation of the main research findings for each of the eight parks studied, followed, in section 5, by a comparative analysis of the case studies.

\section{Marapendi Municipal Natural Park (MNP)}

Marapendi MNP is usually well frequented, mostly due to the functioning of the Marapendi Environmental Education Center (CEA) within its bounds. The center itself acts as a big stimulus for ecotourism by virtue of its continuous environmental education activities, especially with local/nonlocal public schools. Between March $15^{\text {th }}$ and July $10^{\text {th }}, 2005$, a research study was conducted with the park visitors based on a questionnaire filled out by 61 visitors, with the following results: of the visitors who reported their home district, 62.3\% lived in Recreio and 8.2\% lived in Barra. The remaining 29.5\% came from other districts. $69 \%$ of the sample visited the park only at weekends and $13 \%$ visited the park only on holidays. The remainder visited the park sporadically. Visitors' main complaints concerned the lack of infrastructure (drinking water and bathrooms), cleanliness of the water in the lake, and the 
lack of information about the park and its events. In the manager's opinion, the main negative impacts caused by the visitors on the park were littering (especially close to an area where a wall had fallen) unauthorized hunting and collection of specimens. Beyond the level of the pollution in the Marapendi lagoon, two additional impacts incurred by Marapendi MNP were excess noise and tailpipe emissions caused by vehicles traveling along adjacent avenues. Both these types of pollution jeopardize park fauna as well as visitors' sense of tranquility. Unfortunately, this problem has no obvious solution given the urban growth around the park and the neighborhood's vocation for beach-related recreational activities.

Regarding collaborative actions between the park manager, the community and local businessmen, the initiative of a local public relations/design company was identified: at the end of 2005, the firm had produced a campaign entitled "Preserve" to celebrate the area's natural beauties and raise the awareness of local residents vis-à-vis preserving nature. The campaign was financed by company clients, whose business names and brands were displayed during the course of the initiative. Although the campaign was a success and improved the relationship between the company and park management, the improvement did not sustain. One of the company officers complained about the excessive bureaucracy within the Municipal Secretariat for the Environment (Smac) to get projects approved. With the exception of this initiative, and the leaflets distributed to visitors, no other practical initiatives were identified at the park in the sense of increasing visitor numbers and promoting ecotourism. It can be concluded that, due to the presence of the Environmental Education Center within the park, visitor numbers are satisfactory, especially where organized student groups are concerned. However, a lack of continuity in the efforts of the manager to find partners to help popularize the park was felt, especially in the face of local business interests.

\section{Chico Mendes Municipal Natural Park (MNP)}

Despite the lack of strategic planning at Chico Mendes MNP, visitor numbers have increased in recent years thanks to the manager's efforts in terms of publicity. There are brochures available specifically on the environment and on the park, centrally printed by Smac. Another of the park's strong points, according to the manager, is the guided visits, held from tuesdays through fridays, twice a day, and under special arrangement on sundays, when university biology students, doing internships in the park, act as guides for groups of 
individuals/city schoolchildren. Notably, the case of the interns is one of the few partnerships undertaken by Smac that involves all municipal parks. The NGO Instituto Iguaçu de Pesquisa e Proteção Ambiental (Iguaçu Institute for Environmental Research and Protection) acts as an intermediary for unpaid internships in the municipal natural parks in conjunction with universities and biology departments. This free source of labor helps the manager with guided visits and certain of the park's management operations, as well as conducting research, another objective of a conservation unit. One of the park's most popular attractions is the rearing facility for broad-snouted alligators, an endemic and threatened species, specially due to the pollution of Chico Mendes lagoon. However, this attraction is relatively little exploited, given that it could engender partnerships with businesses that wish to: a) invest in ecotourism ventures in the region; b) protect the specie; c) conserve its natural habitat (the park and surrounding areas); and d) generate tourism income and create jobs for the local low-income population. One of the main environmental problems that jeopardize ecotourism in the park is the pollution of the Chico Mendes lagoon, caused by domestic wastewater illegally discharged by local slums, residential buildings and businesses into it.

\section{Prainha Municipal Natural Park (MNP)}

Prainha MNP has a good visitor infrastructure: public bathrooms and showers, a veranda for events, visitor center with meeting rooms, rooms for science displays and exhibitions, as well as trails that can be followed with or without a guide. However, not all trails are well maintained or well signposted. It was noted that the Environmental Education Center (CEA) in the park was a magnet for ecotourism and visitors, by virtue of the ongoing activities. However, the manager said visitor numbers were highly seasonal due to the park's remote location, and was mostly sought after in the summer and on sunny weekends. Visitor numbers were not obtained from the park, which has its own small descriptive brochure, as well as other brochures on environmental education. The partnership between Instituto Atlantis and the central agency - Smac assures there are always groups of employees (from businesses) visiting the park for recreational and ecological activities related to their professional activities. However, the Association of Surfers and Friends of Prainha (Asap) has been critical of the park's weak efforts in terms of publicity. According to one Asap member, the majority of people who enter the park do so just to use the showers and bathrooms located at the entrance. During the course of the 
study, there was evidence of a simmering conflict between park management and the Asap, something which certainly hampered the implementation of any partnership for the development of ecotourism. Considering the enormous touristic potential of this park, low rate of use was noted.

\section{Bosque da Barra Municipal Natural Park (MNP)}

Several interesting partnerships were identified between the manager of MNP Bosque da Barra and businesses and NGOs. These partnerships combined sports, leisure and environmental education activities, thereby assuring a good visitor turnout on weekends. According to the park manager, some local businesses have partnered with the park in organizing cultural and sports events. In 2005, there had been an extensive program of sunday events, including theater, capoeira classes, musical performances and exhibitions. The voluntary contribution of the sponsoring partner was made in terms of donations of cleaning materials, garbage bags, toilet paper etc., to help with the upkeep, especially during times when there was no central maintenance contract. Another important partnership reported by the manager was with the Ineptus Clã theater troupe, which has specialized in works touching on environmental education since 2001. The group offers eco-theater workshops and performs for free on sundays. In exchange, the company uses the park as its headquarters - even for storing props - and as a showcase to the public and businesses in hopes of gaining contracts to perform at parties and events.

According to the park manager, park visitors are, nowadays generally respectful of rules; however such has not always been the case; the current good visitor behavior is viewed the result of a process of awareness-raising via dialog and eco-theater. With respect to trash, the manager also mentioned a partnership with the city sanitation service to install fixed trash receptacles, and mobile receptacles for saturdays and sundays, days on which picnickers frequent the park. The manager said that, despite a lack of controls or statistics on the number of park visitors, he had an idea of the number of visitors by the number of cars in the parking lot, which has 100 spaces: "... according to estimates, on average we get 5,000 or 6,000 people here a month". It must be emphasized that the admission to the park is free of charge.

Evaluation of compliance of the social dimension of Ecotourism is positive, in view of the fact that park management has been able to create, through informal partnerships, a series of activities that combine leisure, environment and environmental education, while increasing park visitor numbers and rai- 
sing the public's environmental awareness. Not so positive was the manager's heavy emphasis on sporting activities to the detriment of ecotourism activities, research activities and park ecosystem conservation. Furthermore, during the interviews, the manager commented on a plan to build volleyball courts in an area previously occupied by vegetation. His sports inclination would be less problematic if he had the support of biologists or other specialist technicians who might compensate for his deficiencies in the realm of the environment. But in their absence, and as a physical education teacher, he wound up prioritizing activities he was most comfortable with. This was an aspect that could compromise medium term conservation objectives of the park (already highly impacted by humans) distorting the primary concern of nature conservation.

\section{Municipal Natural Park (MNP) Bosque da Freguesia}

One of the biggest challenges to the manager when she took the job at Bosque da Freguesia MNP in 2003 was in getting the local social actors to understand the change in status from public park to natural park. The new status brought changes in how the park would be used by visitors, especially those going for their daily walk. Based on conversations, the changes included: a) activities that were/were not allowed in the park; b) prohibition of bicycle riding in the park (until then a normal practice); c) the issue of open hours (7 AM to $5 \mathrm{PM}$ ) - opening the park an hour earlier than provided for in Smac rules in order not to hamper the early-morning walkers.

The manager made use of the Advisory Council as a forum to discuss the new rules and acted operationally with personnel from the Municipal Environmental Defense Group to orient park users. However, she herself alerted to the need to keep the rules flexible in certain situations, such as the case of the soccer field and the multi-sports court, which, in theory, should be removed from a park-type conservation unit. Thus, the manager also demonstrated that she was there to attend to the needs of the park users, subject to regulatory restrictions.

Regarding partnerships formed during the management for purposes of providing support to leisure/ecotourism activities, in general these were informal, ad hoc affairs, such as the relationship with a local supermarket, which provides breakfast to some of the park's morning events. Publicity for the events is undertaken by a local printer business, at no cost. A bus company has also provided buses for local senior citizens to visit other conservation units. Another local partner that was identified is a bank, which for three ye- 
ars has used the park to hold environmental awareness workshops with local schools. The park provides the speakers and the bank organizes the event with event-animators and snacks. In exchange, the bank has donated equipment and materials to the park, including a drinking fountain.

Undoubtedly, the proactive efforts of Bosque da Freguesia MNP, in its search for partnerships to foster recreation and ecotourism, combined with private initiatives and the existence of an Environmental Education Center (CEA) at the site, seem to be one of the most effective approaches among the municipal parks studied. However the consequent increase of daily visitors has created environmental problems, especially to the reproduction of the local species. The interviews seem to indicate that the existence of an Advisory Council, the only one functioning among the municipal parks at the time, facilitated contact with businesses and fostered the formation of a network of informal partnerships with the park. Notably, though, the functioning of the Council was pivotal in terms of the relationship crisis between manager, Friends of Freguesia Park, and the Residents and Friends of Freguesia Association, when she tried to implement the closure of the park on mondays, according to NSCU law, in order to protect local flora and fauna. That conflict terminated with the manager leaving the park within a few months of the closure of this study.

\section{Municipal Natural Park (MNP) Penhasco Dois Irmãos}

Visitor numbers and tourism in this park are still weak. This is due to: a) its location at the top of a hillside (thereby hampering access on foot); b) scant awareness of the park's existence, and; c) the park's proximity to a favela (slum) known as Vidigal, an aspect that inhibits many visitors fearful of possible shootouts in the region. The park manager emphasized that this risk does not exist inside the park. Recently, the park has become the destination of foreign tourists brought by tourist excursions with safari jeeps. The manager estimates that visitors number around 450 or 500 at weekends. However, the most assiduous users are the local residents themselves, especially children, from favela Chácara do Céu, who use the park as their leisure area. At the time the data was being gathered, there was even a recreation/environmental education project for local children being coordinated by a Smac environmental agent and the leader of the Community Reforesting Initiative, both favela residents. The project includes capoeira, folk art and dance. There are also environmental educational classes for children. 
The manager of Penhasco Dois Irmãos MNP mentioned that one of his main objectives was to host environmental education/awareness talks at the park in order to foster better awareness of it. Plans might also include guided visits, assuming problems with violence close to the park can be reduced. On the other hand, since visitor numbers are small, visitor impacts on the park are low, easing maintenance concerns. However, no partnerships whatsoever were identified in terms of increasing visitor numbers. In conclusion, the objective is not being met fully, despite the manager's good intentions - especially in view of the problems with violence in the vicinity, which create a false image of insecurity in the park. A certain difficulty in establishing partnerships was also noted, whether with residents' associations/business people, whether with environmental NGOs.

\section{Pedra Branca State Park}

The Pedra Branca State Park constitutes the largest urban park in the world, with 12,500 hectares spread around Pedra Branca Mountain. Its extension and location mean that the park shares a boundary with some 17 municipal districts, covering one third of the municipal population. Research studies conducted by the Environmental State Secretariat (IEF-RJ) in 2001 and 2005 in the municipality of Rio de Janeiro revealed, however, that the local population still does not know the park as well as might be hoped. Studies conducted in 2001 showed that only 1\% of the Rio de Janeiro population was familiar with Pedra Branca State Park, which is translated into very low visiting rates. Despite its importance in terms of the conservation of the flora and fauna of the Atlantic Forest within the municipality, due to its vast biodiversity, the park is seriously threatened by growing urban pressures.

At the time of the research, the Pedra Branca Park was still without any kind of management plan. Due to the financial difficulties found by the management, which in 2003 assumed responsibility to hire a company to undertake the necessary studies, provisional general rules were implemented for public use, through a decree, which even allowed for charging admission (still not in effect). According to IEF-RJ's Conservation Director, during the study, the management plan started being implemented on third-party basis in 2004. The management plan would orient all actions to be developed for park management and park zoning, the latter including all areas where it would be possible to develop public access projects (ecotourism for example), with huge potential for the park. The study would indicate the touristic potential 
of the park, the civil society surrounding the park and all pertinent economic, socioenvironmental and sociocultural aspects. At the time of the study, the socioenvironmental study - a preliminary stage of the management plan for Pedra Branca Park - was underway and expected to be concluded by yearend, which did not occur. With the 2007 change in management at IEF-RJ, the socioenvironmental study was reviewed by the new Conservation Administration. During the research, just one formal partnership was identified (with a university, to install signposting for the park trails), something that underscores the precariousness of ecotourism at that location. However, the use of environmental education as a strategy for increasing the number of visitors at the park, especially students who visit the park's Environmental Education Center, proved to be a promising option.

\section{Tijuca National Park}

The main attraction of Tijuca National Park is Corcovado Peak, where the Christ the Redeemer statue is located, perhaps Rio de Janeiro's largest tourist attraction, as well as its symbol. According to the coordinator of the park management plan, around one million people every year visit the park, 65\% visiting Corcovado, and the rest to other areas; however there are no precise controls in areas such as Paineiras and Floresta da Tijuca. In order to accommodate the vast numbers of visitors, largely comprised of foreigners, the Tijuca National Park developed a partnership with Rio de Janeiro City Hall and businesses operating at Corcovado. Furthermore, the Friends of Tijuca National Park are active in the management of the financial resources contributed by one of the partners. According to the park manager, the partnership involves the conservation of the park area, cleaning services, two snack kiosks, a tourist information booth, and parking; she reported that things worked adequately well. She also confirmed that the partnership was being reviewed by her, in order to place new demands before the partners. Note that tourism at Corcovado cannot be characterized as ecotourism; it is, rather, mass tourism, with concomitant serious impacts, insufficiently studied, on the local environment. Furthermore, despite generating huge revenues, the money goes directly into a Federal Fund, with only a small portion of sales being reinvested in the park. The Tijuca Park is provided with an ecotourism sector, which produces publicity and environmental education materials and schedules a range of ecotourism activities, including guided park trail hikes and community cleanup events. These activities are free. 
Considering the aspect of abandonment observed by the researcher in certain areas of the park (especially in Floresta da Tijuca area), the frequent robberies of tourists in certain areas of this sector of the park, the harassment of tourists by false tourism guides around the Corcovado railway station, and the illegal transportation services that operate on the road to Corcovado (all of which are frequently denounced by the newspapers), one can say that Tijuca National Park, too, has difficulty in fully meeting the objective of catering well to the countless visitors. Considering the success of the multiple partnerships at the top of Corcovado, it can be speculated that the formation of new partnerships with businesses and NGOs is opportune, with the adoption of trails and tourist attractions sponsored by them, thus incorporating ecotourism into the park's activities.

\section{Discussion of results}

The cross-park analysis sought to find similarities and differences in terms of the collaborative strategies employed and results achieved for ecotourism and recreational activities, as a function of: managers' actions; the actions of their respective central agencies; and the local specificities of each park.

Chart 2 summarizes the main points regarding the cases, with certain conclusions being drawn. In analyzing the eight parks in terms of infrastructure, development of recreational activities in contact with nature and ecotourism activities, it can be concluded that, with respect to providing recreational activities to visitors, the parks studied managed to reach satisfactory performance levels. In general, they are adequately equipped and maintained, and have cultural activities linked to the environment, above all for children. But, it is in the area of ecotourism that the parks of Rio de Janeiro here studied present, almost without exception, their worst performance. Overall, trails are generally poorly signposted and parks lack of human resources adequately trained to orient ecotourists. The municipal parks, for example, use internship students as guides in order to compensate the lack of professional guides. Security issues are common, especially since some of the parks studied (Tijuca, Pedra Branca and Penhasco Dois Irmãos) are surrounded by favelas dominated by drug dealers. Even Tijuca National Park, the visitor champion, is sought mostly for its mass tourism attractions, such as trips to Corcovado and Pedra Bonita. The management of ecotourism in the studied parks of Rio appears to diverge from recommendations found in literature towards incre- 
asing professionalization (Boyd and Butler, 1996; Almeida and collaborators, 1999; Seabra, 2001; Davenport and collaborators, 2002; Pasquali, 2006) and greater interactivity with local communities (Ross and Wall, 1999; ValladaresPadua and collaborators, 2001; Costa, 2002). Is was also found that none of the agencies responsible for managing ecotourism and recreation in the parks have a specific set of indicators to adequately measure the effectiveness and sustainability of their recreation and ecoturism iniatives, as proposed by different authors, such as Ross and Wall (1999); Davenport and collaborators (2002); Bellen (2004).

With respect to strategies, there seems to be no collaborative, or even competitive, strategy for the development of tourism in the city's conservation units studied, within the realm of the central agencies responsible. It was noted that just one of the parks (Tijuca) had a Management Plan at the time the research was conducted. This point is an indicator that the ecotourism activities of the other parks were still in the planning/implementation phase, or else functioning precariously, since such an instrument should be the basis for the design of a strategic ecotourism plan within each park, according to NSCU (Brazil, 2000). All of the municipal parks lack planning and centralized support for the planning of ecotourism initiatives, in opposition to what is suggested in the literature (Cater, 1993; Almeida and collaborators, 1999; Seabra, 2001). Pedra Branca State Park also appears to lack an implemented strategic plan. The Federal Environmental Secretariat (Ibama), responsible for Tijuca National Park, despite myriad problems, manages to plan its mass tourism activities and with some success, thanks to the existence of a management plan. But the success of its mass tourism has jeopardized the efforts to preserve some natural areas of the park and to increase the volume of ecotourism activities. All of the parks studied seek, in different degrees, to form partnerships with businesses and third sector organizations in order to increase park visitor numbers, as suggested by Ross and Wall (1999) and other authors (Davenport and collaborators, 2002; Pasquali, 2006). While in Pedra Branca State Park and Tijuca National Park this effort occurs in a centralized way, for municipal parks managers seek to compensate for deficiency of central planning by forming informal partnerships with local businessmen and citizens' associations.

It was also identified that all three central environmental agencies (Federal Ibama, State IEF-RJ and Municipal Smac) prioritize environmental education activities by means of formal partnerships with Education Secretariats in their own spheres of government and third sector organizations. Thanks to 
the synergy between environmental education and ecotourism activities, the parks with Environmental Education Centers (CEA) do get some partial benefit in terms of high visiting rates and higher visibility within the community, confirming Orams' (1997) findings about the important role of ecotourism for environmental education.

With respect to the contribution of recreation and ecotourism activities for park sustainability, which would measure, to some degree, the effectiveness of implemented strategies and of management in general, it could be seen that, on average, environmental sustainability was not affected in a particularly positive way. The overall average assessment of this dimension for the eight parks was "low". In some cases, such as Tijuca National Park, Bosque da Barra MNP and Bosque da Freguesia MNP, the environmental sustainability is actually threatened by the numbers of visitors, who can exceed the load capacity of the protected area, a common problem to other natural parks all over the world, as stated by Orams (1995); Ross and Wall (1999) and Western (1999).

In relation to the contribution of visitors and ecotourism to financial sustainability, the effect for the parks is almost nil, even including Tijuca National Park. The overall average assessment of this dimension for the eight parks was "very low". This point seems to be crucial to the survival of the parks. It becomes necessary to create mechanisms that would enable state and municipal central agencies to charge entry to the parks, as well as to seek, in a more professional way, partnerships with private initiatives, environmental NGOs, and financing from seed-money agencies. The organizational structure itself must change, since agencies, as well as current managers, lack material/ human resources and spend the majority of their time concerned with purely operational concerns in order to assure basic services.

With respect to the social sustainability of the park and its environs, these are more highly impacted by the contribution of visitors and ecotourism, especially due to the beneficial effects to the physical/mental health of visitors, and the possibility of fostering ecocultural activities - and even a little income for poorer communities, as suggested by Ross and Wall (1999). The overall average assessment of this dimension for the eight parks was "fair". Rio de Janeiro parks are an obvious choice for those wishing to appreciate natural beauties, whether from an environmentalist perspective, whether for the practice of sports linked to nature. However, systematic publicity as well as an adequate awareness of Rio de Janeiro parks among environmentally aware tourists appears to be lacking. 


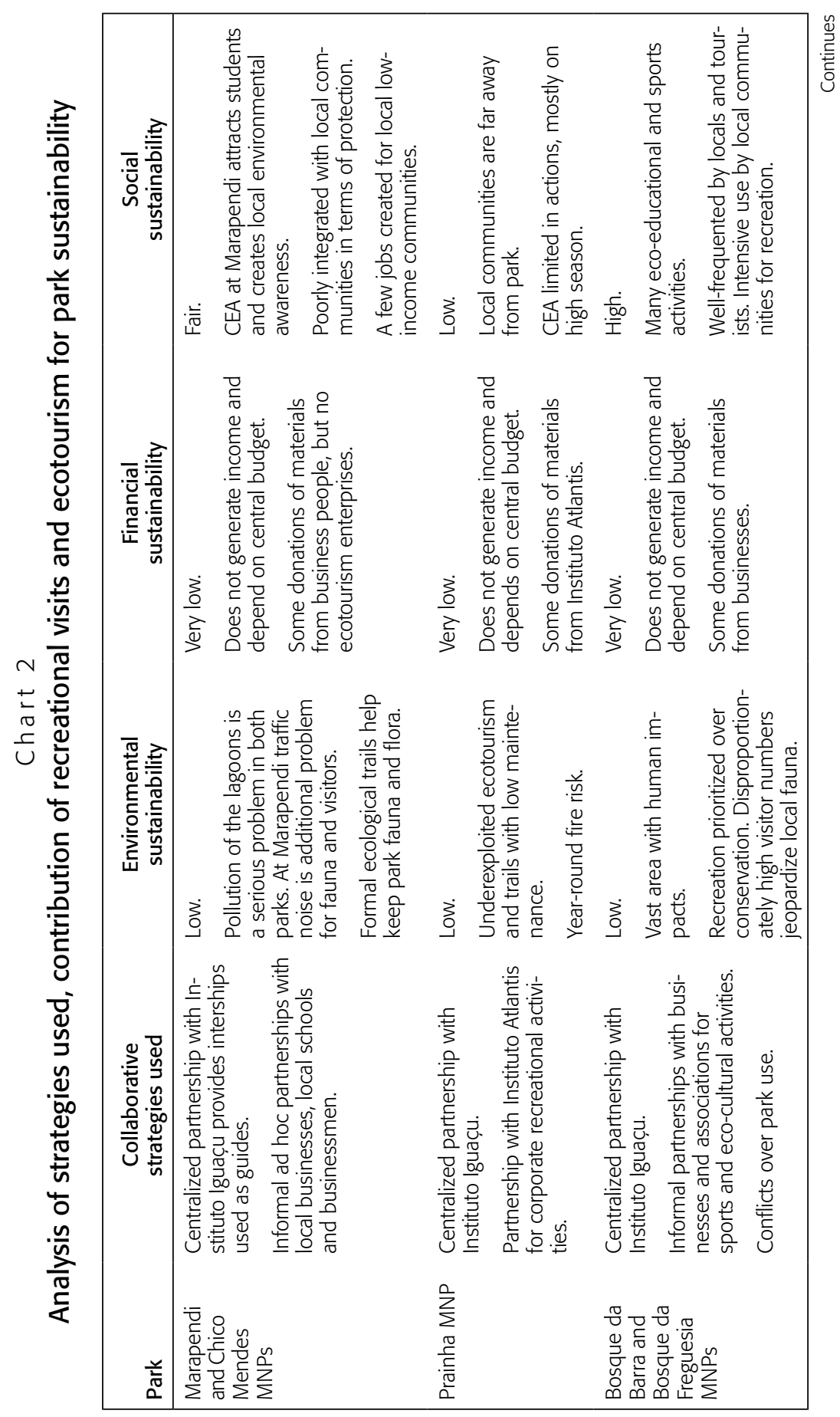




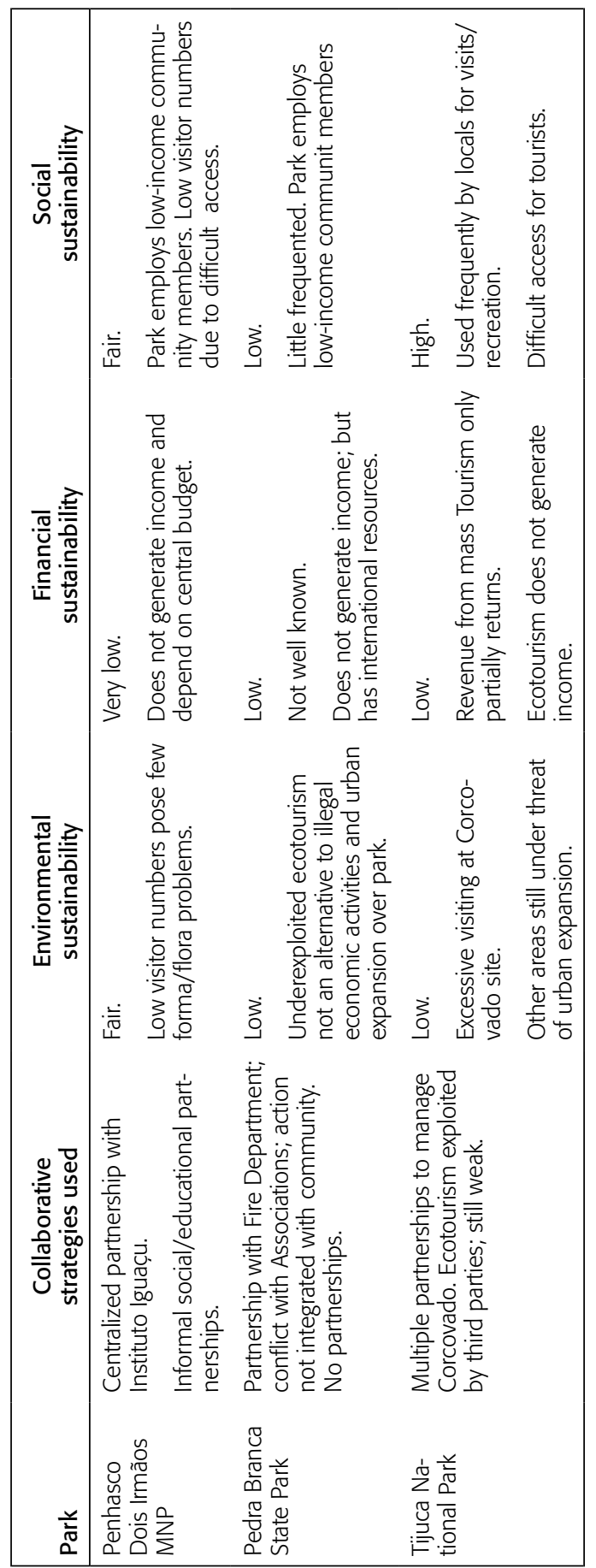




\section{Conclusions and recommendations}

Based on the data analyzed (representative of the state of affairs in the city), it was reasonable to conclude that the ecotourism objective in the eight parks studied in Rio de Janeiro is still far from being successfully implemented, although the recreational objective is already fairly achieved in most of the sampled parks. The cases studied have also illustrated different forms of park management partnerships with varied organizations, most of them unable to change the precarious situation of ecotourism on those parks. The Federal and State parks basically adopt centralized collaborative strategies while the municipal parks suffer from the lack of central planning, except for environmental education.

The results suggest the urgency to develop a strategic model for planning, implementation and management of ecotourism projects for the natural parks of the city of Rio de Janeiro, with explicit mechanisms to handle the identified problems, within a systematic approach, as proposed by the various authors mentioned earlier, especially Ross and Wall (1999) and Davenport and collaborators (2002). Such a model would include the definition of critical ecotourism performance indicators - which should be associated with the functions and objectives of each ecotourism venture, something that certainly varies from one place to the next. Considering that the lack of human and financial resources is system-wide in most governmental agencies in Rio de Janeiro, it seems reasonable to affirm, based on the results of this study, that the effective use of collaborative strategies could become an important tool for improving the management of natural parks in Rio de Janeiro.

Based on data analyzed, the fusion of environmental education with ecotourism and recreation appears to be another fundamental strategy for successful management of the parks. By becoming familiar with the park, the population becomes easier to mobilize in order to act as its steward, or, at least not to desecrate it.

Considering the need for planning, it is perceived that ecotourism is a complex phenomenon that involves the integration of diverse stakeholders including tourists, local community, government, for/not for profit organizations, thus forming a complex network of myriad relationships and interdependencies between, economic, political, technical, social, ecological and cultural subsystems. In this way, the sustainable development of natural parks and their surroundings entails a highly complex implementation, due to the antagonistic interests in play. More recently, countless experiences of cooperative project governance of environmental conservation rural and urban areas 
have been reported around the world (Presas, 2001) and in Brazil, in particular (Souza, 2002; Oliva and Magro, 2004), with many involving ecotourismrelated activities. The common thread in all these experiences is that, with the identification of all of the different stakeholders as well as their motives, it was possible to structure a corporative network, in such a way that the conflicts existing between the involved parties were resolved by means of mutual understanding. This also underscores the fundamental importance of the active participation of local communities and of other stakeholders for the success of any ecotourism venture, as recognized by NSCU law.

More research is needed to better understand the use of collaborative strategies to deal with ecotourism issues in natural parks in order to achieve an adequate level of sustainability. It seems that only with the will of the political leadership and ample partnerships between the three spheres of government and private initiatives can ecotourism become a source of income for the population, funding for the parks, and an instrument for park conservation.

\section{References}

ALMEIDA, Regina de et al. Ecoturismo na web: um programa de ensino a distância para professores e alunos. LemadiI/AVT, Departamento de Geografia/FFLCH/USP, 1999.

BARBOSA, Marciana Alves. O ecoturismo e a sustentabilidade - Parque Estadual da Serra Dourada - GO. 2008. Dissertação (Mestrado) — Universidade Católica de Goiás, Goiânia.

BELLEN, Hans Michael van. Indicadores de sustentabilidade: uma análise comparativa. In: EnANPAD, 28. Anais... Curitiba, 2004.

BOYD, Stephen; BUTLER, Richard W. Managing ecoturism: an opportunity spectrum approach. Tourism Management, v. 17, n. 8, p. 557-566, 1996.

BRAZIL. Lei no 9.985, de 18 de julho de 2000. Regulamenta o art. 225, §1ํㅡ, incisos I, II, III e VII da Constituição Federal, institui o NSCU da natureza e dá outras providências. Ministério do Meio Ambiente, Brasília. Available at: <www.mma.gov. br/port/sbf/dap/doc/NSCU.pdf > . Accessed on: Apr. 15 ${ }^{\text {th }}, 2006$.

CATER, Erlet. Ecotourism in the Third World: problems for sustainable tourism development. Tourism Management, Apr. 1993.

CEBALLOS-LASKURÁIN, Hector. O ecoturismo como fenômeno mundial. In: HAWKINS, Donald. Ecoturismo: um guia para planejamento e gestão. 2. ed. São Paulo: Senac, 1995. 
COSTA, P. C. Unidades de conservação. São Paulo: Aleph, 2002.

CRESWELL, John W. Research design: qualitative, quantitative and mixed methods approaches. 2. ed. Sage Thousand Oaks, 2003.

DAVENPORT, Lisa et al. Ferramentas de ecoturismo para parques. In: TERBORGH, John et al. (Orgs.). Tornando os parques eficientes: estratégias para conservação da natureza nos trópicos. Curitiba: UPR, 2002.

EGLER, Ione. Perspectivas brasileiras de desenvolvimento sustentável. In: SEMINÁRIO DE DESENVOLVIMENTO SUSTENTÁVEL E PODER LOCAL. Anais... Unicap/Ausjal. Recife, nov. 1999.

OLIVA, A.; MAGRO, T. C. A evolução do planejamento do entorno das unidades de conservação de proteção integral. In: CONGRESSO BRASILEIRO DE UNIDADES DE CONSERVAÇÃO, 4. Anais... 2004.

OLIVEIRA, C. A.; SANTOS, C. J. F. Florestas urbanas: normas de uso e ocupação do solo para proteção de unidade de conservação nas cidades. In: CONGRESSO BRASILEIRO DE UNIDADES DE CONSERVAÇÃO, 4. Anais... v. 1, 2004.

OLIVEIRA, Luciano A. Mapeamento semântico do turismo sustentável. Boletim Técnico do Senac, Rio de Janeiro, v. 30, n. 1, p. 13-20, 2004.

ORAMS, Mark B. Towards a more desirable form of ecotourism. Tourism Management, v. 16, n. 1, p. 3-8, 1995.

.The effectiveness of environmental education: can we turn tourists into "greenies". Progress in Tourismand Hospitality Research, v. 3, p. 295-306, 1997.

PASQUALI, Rejane. Parcerias público-privadas na gestão dos serviços turísticos em parques nacionais: possibilidades para o Parque Nacional da Chapada dos Guimarães. Dissertação (Pós-graduação) — Universidade do Vale do Itajaí (Univali), Camboriú, 2006.

PCRJ-SMAC (Prefeitura do Rio de Janeiro/Secretaria Municipal do Meio Ambiente). Relatório de Gestão da Secretaria Municipal de Meio Ambiente no período 1994-2004. Rio de Janeiro: Smac, 2004.

PRESAS, Teresa. Interdependence and partnership: building blocks to sustainable development. Corporate Environmental Strategy, v. 8, n. 3, 2001.

ROSS, Sheryl; WALL, Geoffrey. Ecotourism: towards congruence between theory and practice. Tourism Management, n. 20, p. 123-132, 1999.

SACHS, Ignacy. Estratégias de transição para o século XXI, desenvolvimento e meio ambiente. São Paulo: Studio Nobel, 1993. 
SCHEYVENS, Regina. Ecotourism and the empowerment of local communities. Tourism Management, n. 20, p. 245-249, 1999.

SEABRA, G. F. Ecos do turismo: o turismo ecológico em áreas protegidas (Coleção Turismo). Campinas, SP: Papirus, 2001.

SOUZA, Ilma et al. Dipuc - Diagnóstico participativo de unidades de conservação. In: III CONGRESSO BRASILEIRO DE UNIDADES DE CONSERVAÇÃO, 3. 2002, Fortaleza. Anais... Fortaleza: Rede Nacional Pró Unidades de Conservação Ambiental, 2002.

TCMRJ (TRIBUNAL DE CONTAS DO MUNICÍPIO DO RIO DE JANEIRO). Auditoria operacional em unidades de conservação. Rio de Janeiro, 2005.

THE INTERNATIONAL ECOTOURISM SOCIETY. Declaração do Ano Internacional do Ecoturismo-2002. Disponível em: <www.ecotourism.org>.

VALLADARES-PADUA, Claudio; PADUA, S. M.; CULLEN Jr., L. Within and surrounding the Morro do Diabo State Park: biological value, conflicts, mitigation and sustainable development alternatives. Environmental Science \& Policy, n. 5, p. 67-78, 2002.

WESTERN, David. Definindo o ecoturismo. Ecoturismo: um guia para planejamento e gestão. 2. ed. São Paulo: Senac, 1999.

YIN, Robert K. Case study research — design and methods. 2. ed. Sage, 1994. 